УДК 636.22/28.082.033

(C) 2012

Дедова Л. О., молодший науковий співробітник

Інститут розведення і генетики тварин

\title{
ОЦІНКА РОСТУ ТЕЛИЦЬ РІЗНИХ ЛІНІЙ СТВОРЮВАНОЇ СИМЕНТАЛЬСЬКОЇ М'ЯСНОЇ ПОРОДИ
}

\section{Рецензент - кандидат сільськогосподарських наук Ю. І. Криворучко}

\begin{abstract}
Наведено результати досліджень росту телищь різних ліній створюваної симентальської м'ясної породи. Доведено, щзо лінійні телиці відрізняються високою живою масою, - свідченняо здатності до високої м'ясної продуктивності. Враховуючи сучасні вимоги ринкової економіки, найважливішим напрямом селекції є створення на базі сучасної симентальської м'ясної породи нової української симентальської м'ясної породи, здатної впродовж тривалого часу зберігати високу інтенсивність росту при повільному накопичені жиру.
\end{abstract}

Ключові слова: жива маса, середньодобові прирости, м'ясне скотарство, порода.

Постановка проблеми. Збільшення виробництва м'яса наразі є одним із першочергових завдань. При цьому головним напрямом збільшення його обсягів вважається прискорений ріст виробництва яловичини, частка якої в загальному виробництві м'яса становить понад 50 \%. Ї̈̈ споживання в розрахунку на душу населення поки що не відповідає науково обгрунтованим нормам. Виходячи зі світового досвіду, вирішити цю проблему і ліквідувати дефіцит м'яса можна за рахунок розвитку галузі спеціалізованого м'ясного скотарства.

Аналіз основних досліджень і публікацій, у яких започатковано розв'язання проблеми. Для розв'язання цієї проблеми необхідно створити вітчизняні конкурентоспроможні м'ясні породи, використовуючи місцевий та кращий світовий генофонд. Про це свідчать досягнення у м'ясному скотарстві США, Канади, Франції, Великобританії та інших розвинених країн, а також наукові та виробничі доробки вчених i практиків України. В результаті багаторічної цілеспрямованої селекційно-племінної роботи науковців і практиків створені українська, волинська, поліська і південна м'ясні породи та знам'янський тип поліської м'ясної породи $[1,2,3]$. Крім того в Україні розводиться в невеликій кількості худоба імпортних м'ясних порід, зокрема шароле, абердин-ангуська, лімузинська, герефордська та інші.

Дослідження показують, що для більшості м'ясних порід характерна малочисельність, а відтак і низька жива маса телят при відлученні. 3 метою підвищення живої маси їм додатково згодовують концентровані корми, що супроводжується подорожчанням прибутку [4]. Це $є$ стримуючим фактором розвитку м'ясного скотарства в умовах ринкової економіки.

Досвід багатьох країн світу, особливо європейських, доводить, що симентальська порода має високу м'ясну та молочну продуктивність $\mathrm{i}$ майже не поступається шароле, переважаючи всі інші м'ясні породи. Тому процес створення української симентальської м'ясної породи дає змогу одержати більш важких телят при повільному накопиченні жиру i високим виходом м'язової тканини.

Слід зазначити, що до цього часу не проводилося порівняльного вивчення росту й розвитку телиць створюваної симентальської м'ясної породи різних ліній в умовах промислової технології.

Мета дослідження - провести порівняльне вивчення особливостей росту і розвитку телиць різних ліній створюваної симентальської м'ясної породи.

Матеріал та методика дослідження. Для виконання поставленої мети проведені виробничі досліди в ПАТ «Дніпровське » Бориспільського району Київської області. Об'єктом дослідження були телиці різних ліній: Метца 529019743, Ахілеса 369, Абрікота 58311, Хакела 19223953, Геркулеса 894246, Сигнала 120 створюваної симентальської м'ясної породи.

Від народження до 7-місячного віку телиці утримувалися на підсосі. Для визначення росту телиць їх щомісячно зважували; на основі цього вираховувалися середньодобові прирости. Одержані результати досліджень оброблені методом варіаційної статистики за Н. А. Плохінським (1969).

Результати дослідження. Найважливішим показником росту тварин $\epsilon$ їх жива маса. Телиці різних генотипів за однакових умов годівлі та утримання проявили схожу інтенсивність росту живої маси (див. табл.). 


\begin{tabular}{|c|c|c|c|c|c|c|c|}
\hline \multicolumn{10}{c|}{ Динаміка жнвої маси телиць різних ліній, кг } \\
\hline \multirow{2}{*}{ Вік, міс. } & \multicolumn{7}{c|}{ Лінія, споріднена група } \\
\cline { 2 - 8 } & $\begin{array}{c}\text { Метца } \\
5290\end{array}$ & $\begin{array}{c}\text { Ахілеса } \\
369\end{array}$ & $\begin{array}{c}\text { Абрікота } \\
58311\end{array}$ & $\begin{array}{c}\text { Хакела } \\
19223\end{array}$ & $\begin{array}{c}\text { Геркулеса } \\
8942\end{array}$ & $\begin{array}{c}\text { Сигнала } \\
120\end{array}$ & $\begin{array}{c}\text { Стандарт } \\
\text { породи }\end{array}$ \\
\hline $\begin{array}{c}\text { Ново- } \\
\text { народжені }\end{array}$ & $32,3 \pm 0,96$ & $32,6 \pm 1,09$ & $31,5 \pm 1,00$ & $30,5 \pm 1,18$ & $30,4 \pm 0,69$ & $30,3 \pm 0,78$ & - \\
\hline 7 & $195,4 \pm 4,29$ & $197,3 \pm 5,02$ & $196,74,54 \pm$ & $190,4 \pm 3,95$ & $186,5 \pm 4,58$ & $185,1 \pm 3,50$ & 185 \\
\hline 12 & $293,3 \pm 4,93$ & $300,1 \pm 6,64$ & $292,7 \pm 4,56$ & $289,7 \pm 4,57$ & $280,5 \pm 7,51$ & $283,1 \pm 7,01$ & 275 \\
\hline 15 & $341,7 \pm 5,74$ & $347,7 \pm 6,62$ & $346,5 \pm 4,37$ & $339,9 \pm 5,42$ & $330,4 \pm 7,57$ & $334,9 \pm 8,47$ & 375 \\
\hline 18 & $420,3 \pm 6,68$ & $424,4 \pm 7,97$ & $421,4 \pm 6,41$ & $409,4 \pm 8,13$ & $400,3 \pm 8,07$ & $403,0 \pm 8,85$ & 400 \\
\hline
\end{tabular}

Примітка: * Вимоги інструкції з бонітування великої рогатої худоби (І класу). - К. : Арістей, 2007. $-64 \mathrm{c}$.

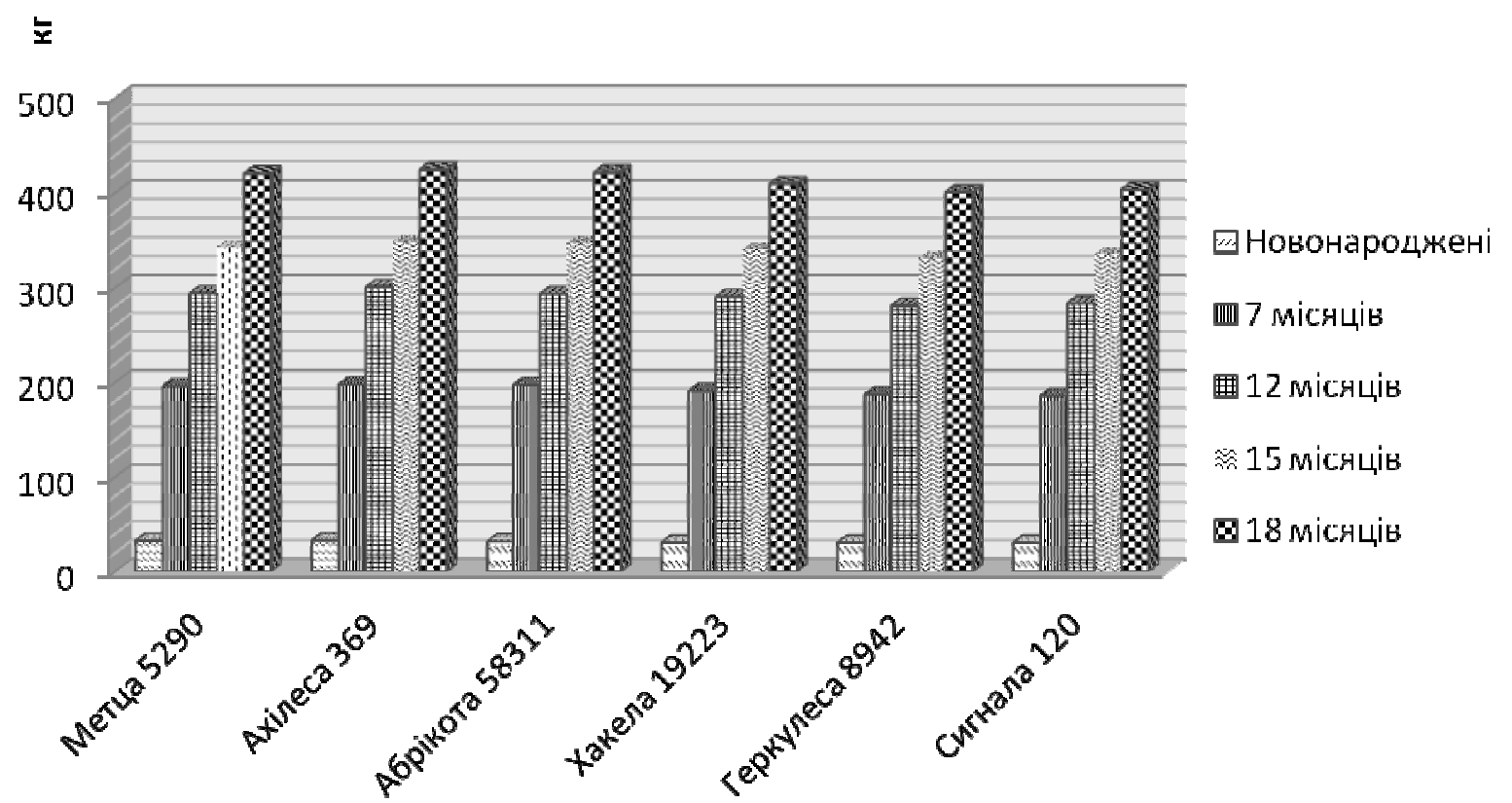

Рис. Динаміка живої маси телиць різних ліній, кг

Iз даних таблиці видно, що телиці всіх генотипів народжуються 3 невисокою живою масою (30,3-32,6 кг), а тому отелення проходять без ускладнень.

Необхідно відзначити, що за цим показником між телицями різних ліній суттєвої різниці не виявлено (див. рис.).

Дослідження показали, що телиці ліній Метца, Ахілеса й Абрікота більш інтенсивно розвивалися, досягши у 18-місячному віці живої маси

\section{БІБЛІОГРАФІЯ}

1. Буркат В. Г. Концептуальні підходи до формування галузі м'ясного скотарства // Тваринництво України. - №4. - 1997. - С. 9-11.

2. Доротюк E. M. Сучасний стан і перспективи розвитку м'ясного скотарства в Україні / Е. М. Доротюк, М. І. Карташов, В. Г. Прудніков // Проблеми зооінженерії та ветеринарної меди-
420,3-424,4 кг. За цим показником вони перевершували аналогів лінії Геркулеса і Сигнала на 17-24 кг; різниця не вірогідна.

Висновки. Враховуючи сучасні вимоги ринкової економіки, найважливішим напрямом селекції є створення на базі сучасної симентальської м'ясної породи нової української симентальської м'ясної породи, здатної впродовж тривалого часу зберігати високу інтенсивність росту при повільному накопичені жиру.

цини. - Вип. 3. - Х., 1998. - С. 3-7.

3. Доротюк E. М. М'ясне скотарство - джерело високоякісної яловичини та шкіряної сировини. - Х. : Тираж $-51,2006 .-320$ с.

4. Зубещь М. Українська симентальська м'ясна порода / М. Д. Зубець, Е. М. Доротюк // Тваринництво України. - №1 1. - 1997. - С. 16-18. 